\title{
Characteristics of premorbid stage in patients with treatment-resistant depression
}

\author{
Vasile Chiriță, Roxana Chiriță, Ghenadie Cărăuşu
}

Vasile Chiriță - Acad. M.D., Ph. D., Professor, Department of Psychiatry, Senior Psychiatrist, „Socola”Institute of Psychiatry, Iași, România; Member of Romanian Academy of Medical Sciences

Roxana Chiriță - M.D., Ph. D., Professor, Department of Psychiatry, Iași „Grigore T. Popa”; University of Medicine and Pharmacy, Senior Psychiatrist, „Socola” Institute of Psychiatry, Iași, România

Ghenadie Cărăuşu - M.D., Ph. D., Associate Professor, Department of Psychiatry, Alcoology and Medical Psychology „Nicolae Testemiţanu” State University of Medicine and Pharmacy, Chisinau, Republic of Moldova

\section{ABSTRACT}

Introduction: The burden of treatment-resistant depression (TRD) is represented by the strong impact on patient functionality, significant deterioration of the quality of life, isolation and stigmatization of the individual. TRD patients incur the highest direct and indirect medical costs among those with major depressive episode, costs that increase with disease severity.

Purpose: To study the role of predisposing and precipitating factors in the emergence, development and maintenance of TRD.

Methods: Descriptive cohort study of 612 patients with TRD, using methods of clinical research, psychological tests, analytical epidemiology, descriptive epidemiology, and mathematics.

Results: The factors predisposing to the development of TRD have been systematized. It has been clearly demonstrated that affective, somatic, and stress-related disorders in TRD patient family are the most common hereditary factors. Disappointment, low level of emotional support during childhood $(p<0.05)$, loss of one parent $(p<0.01)$, use of physical force in children ( $p<0.05$ ), anxiety as a personality trait in the premorbid period $(p<0.05)$, and introversion $(p<0.05)$ are other factors that have statistical significance. 
Conclusions: The determining role of precipitating factors in TRD triggering and of favoring factors in its maintenance have been identified. The impact of personal negative stressful events such as abandonment, separation, divorce, death was demonstrated.

\section{KEYWORDS:}

Major depressive episode, treatment-resistant depression, psychotraumatic situations.

\section{INTRODUCTION}

Six point six percent of adults in the United States had a depressive disorder in the last year (1) and only one in five received adequate treatment in the acute phase. $(2,3)$ Patients whose depressive disorder does not respond satisfactorily to appropriate treatment clearly have a more difficult to treat depressive disorder, generally referred to as TRD. Although often defined in this way, TRD is a complex phenomenon, influenced by the heterogeneity of depressive subtypes, psychiatric comorbidity and coexisting medical conditions. (4) Although TRD is most commonly associated with a major depressive episode (MDE), it can also be seen in the depressive phase of bipolar disorder, which affects $2.6 \%$ of the US adult population each year. (5) The burden of this pathology is represented by the strong impact on patient functionality, significant deterioration of the quality of life, isolation and stigmatization of the individual. (6) TRD patients incur the highest direct and indirect medical costs among those with MDE, costs that increase with TRD severity. (7) Also, these patients are twice as likely to be admitted to hospital, and the cost of hospitalization is more than six times higher than the total average cost for depressive patients who are not resistant to treatment. (8) Predisposing and precipitating factors play an important role in the development and maintenance of TRD.

\section{PURPOSE}

To study the role of predisposing and precipitating factors in the emergence, development and maintenance of TRD.

\section{MATERIALS AND METHODS}

The paper is based on a descriptive cohort study of 612 patients with TRD, using clinical research methods, psychological tests, analytical epidemiology, descriptive epidemiology, and statistical tests. For statistical processing were used: Fisher's exact test, ANOVA method, discriminant analysis procedure, error calculation, " $t$ " test and "p" accuracy degrees, table and graphical procedures, rate calculation, mean values, standard errors, relative risk, and confidence interval, $\chi 2$. The data on the score dynamics after two previous treatment courses according to the Montgomery-Asberg rating scale allowed the selection of a group of 67 (10.9\%) patients with unsatisfactory clinical response. Thus, the 612 patients were divided into two groups. Group I included 545 (89.1\%) patients, and research group II - 67 $(10.9 \%)$ patients.

\section{RESULTS}

Premorbid data of patients with depressive disorders are of major importance for the use of diagnostic and treatment algorithms (9). Therefore, in the collection of anamnestic data, numerous entries need to be filled in, common to all clinical specialties:

- family history, history of psychiatric disorders, including cases of suicide, alcohol dependence, but also other 
chronic diseases patient's relatives have suffered or are suffering from;

- personal medical history (somatic diseases, head injury), etc.

But in the process of biographical data collection from psychiatric patients through interview, some fields will be filled in for:

- patient's perception of parents' marital relationship;

- psychotraumatic situations in childhood;

- premorbid personality, usually based on self-description and completed with information from close friends, companions, and relatives;

- conflictual family environment;

- harmful behavior in the premorbid period.

The clinical-anamnestic research method allows for a more adequate application of the therapeutic strategy by taking into account the time link between symptoms, different conditions and harmful factors. In those cases where data cannot be collected directly from the patient, they are obtained from the family member who accompanied the patient to the hospital or the persons who visited him/her, who can also provide additional information on personal and family history, time of onset and severity of the symptoms.

One of our goals was to determine the personal risk factors for the development of resistance. Studies have shown that depressive disorder in either parent is associated with emotional distress in children (10). Hereditary predisposition, the presence of mental disorders in the family, as well as their effects on others environment play an important role in triggering a depressive illness. Genetic vulnerability, family predisposition to affective disorders and especially maternal depression are recognized in the literature as being involved in the determinism of major depressive disorders, being a predictive factor for therapeutic resistance $(11,12)$.

Statistical processing of family history data of both patient groups has shown that affective disorders are the most frequent disorders: in group I 140 cases $(25.69 \%)$ and in group II 18 cases $(26.87 \%),(\chi 2=0.04),(p>0.05)$. This result is in full agreement with the data in the literature (13). A significant number of cases were also_recorded among the patients with a family history of somatic disorders - group I 87 cases (15.96\%), group II - 10 cases $(14.93 \%),(\chi 2=0.49),(p>0.05)$; stressrelated disorders - group I - 60 cases (11.01\%), group II - 11 cases $(16.42 \%),\left(\chi^{2}=\right.$ 1.70), ( $>$ > 0.05); schizophrenia - group I - 56 cases $(10.28 \%)$, group II - 5 cases $(7.46 \%)$, $(\chi 2=0.53),(p>0.05)($ Table 1$)$.

Table 1. Patient characteristics according to family history (absolute and percentage)

\begin{tabular}{|c|c|c|c|c|c|c|c|}
\hline \multicolumn{2}{|l|}{ Disorders } & \multicolumn{2}{|c|}{ Group I } & \multicolumn{2}{|c|}{ Group II } & \multirow[t]{2}{*}{$\chi^{2}$} & \multirow[t]{2}{*}{$\mathbf{p}$} \\
\hline & & Abs & $\%$ & Abs & $\%$ & & \\
\hline \multirow[t]{2}{*}{ Schizophrenia } & Yes & 56 & 10.28 & 5 & 7.46 & \multirow[t]{2}{*}{0.53} & \multirow[t]{2}{*}{$*$} \\
\hline & No & 489 & 89.72 & 62 & 92.54 & & \\
\hline \multirow{2}{*}{$\begin{array}{l}\text { Affective } \\
\text { disorders }\end{array}$} & Yes & 140 & 25.69 & 18 & 26.87 & \multirow[t]{2}{*}{0.04} & \multirow[t]{2}{*}{$*$} \\
\hline & No & 405 & 74.31 & 49 & 73.13 & & \\
\hline \multirow{2}{*}{$\begin{array}{l}\text { Organic mental } \\
\text { disorders, } \\
\text { epilepsy } \\
\text { included }\end{array}$} & Yes & 44 & 8.07 & 7 & 10.45 & \multirow[t]{2}{*}{0.44} & \multirow[t]{2}{*}{$*$} \\
\hline & No & 501 & 91.93 & 60 & 89.55 & & \\
\hline \multirow{2}{*}{$\begin{array}{ll}\text { Use } & \text { of } \\
\text { psychoactive } & \\
\text { substances } & \end{array}$} & Yes & 44 & 8.07 & 8 & 11.94 & \multirow[t]{2}{*}{1.15} & \multirow[t]{2}{*}{$*$} \\
\hline & No & 501 & 91.93 & 59 & 88.06 & & \\
\hline \multirow{2}{*}{$\begin{array}{l}\text { Personality } \\
\text { disorders }\end{array}$} & Yes & 30 & 5.50 & 7 & 10.45 & \multirow[t]{2}{*}{2.57} & \multirow[t]{2}{*}{$*$} \\
\hline & No & 515 & 94.50 & 60 & 89.55 & & \\
\hline \multirow{2}{*}{$\begin{array}{l}\text { Mental } \\
\text { Retardation }\end{array}$} & Yes & 17 & 3.12 & 2 & 2.99 & \multirow[t]{2}{*}{0.01} & \multirow[t]{2}{*}{$*$} \\
\hline & No & 528 & 96.88 & 65 & 97.01 & & \\
\hline \multirow{2}{*}{$\begin{array}{l}\text { Stress-related } \\
\text { disorders }\end{array}$} & Yes & 60 & 11.01 & 11 & 16.42 & \multirow[t]{2}{*}{1.70} & \multirow[t]{2}{*}{$*$} \\
\hline & No & 485 & 88.99 & 56 & 83.58 & & \\
\hline \multirow[t]{2}{*}{ Cancer } & Yes & 32 & 5.87 & 6 & 8.96 & \multirow[t]{2}{*}{0.97} & \multirow[t]{2}{*}{$*$} \\
\hline & No & 513 & 94.13 & 61 & 91.04 & & \\
\hline \multirow{2}{*}{$\begin{array}{l}\text { Somatic } \\
\text { disorders }\end{array}$} & Yes & 87 & 15.96 & 10 & 14.93 & \multirow[t]{2}{*}{0.49} & \multirow[t]{2}{*}{$*$} \\
\hline & No & 458 & 84.04 & 57 & 85.07 & & \\
\hline
\end{tabular}




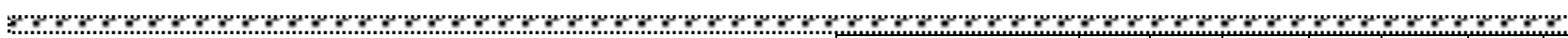

Note: * Statistical significance of results between groups is less than $95.0 \%$ ( $p>0.05$ )

$\mathrm{J}$. Bowlby emphasized the importance, in the first years of life, of the general child-parent attachment process, as well as of the more selective emotional connections (14). Although the connection to the mother was the most important, and the child had to have a very close and secure relationship with her, important connections are also needed with the father, but also with other close relatives. Equally important are a well-established attachment behavior, identification with parents, and adoption of standards. Parents influence their children not only through their individual behavior, but also by the nature of their marital relationship, especially if conflictual. Parental relationship influences the mental development of children. Because of this, the nature of marital relationship is able of generating mental illnesses in children, especially affective disorders.

Also we aimed at identifying other predisposing and predictive factors for therapeutic resistance, namely, early childhood events, e.g. parents' attitudes towards children (Table 2).

Table 2. Characteristics of parents' attitudes towards their children $(\mathrm{Abs}=\mathrm{absolute}$,

\begin{tabular}{|c|c|c|c|c|c|c|c|}
\hline \multicolumn{8}{|c|}{$\%=$ percentage $)$} \\
\hline \multirow[t]{2}{*}{ Attitudes } & & \multicolumn{2}{|c|}{ Group I } & \multicolumn{2}{|c|}{ Group II } & \multirow[t]{2}{*}{$\chi^{2}$} & \multirow[t]{2}{*}{$\mathbf{p}$} \\
\hline & & Abs & $\%$ & Abs & $\%$ & & \\
\hline \multirow[t]{3}{*}{ Abusive } & & 49 & 8.99 & 10 & 14.93 & \multirow[t]{3}{*}{2.41} & \multirow[t]{3}{*}{$*$} \\
\hline & Yes & & & & & & \\
\hline & No & 496 & 91.01 & 57 & 85.07 & & \\
\hline \multirow[t]{2}{*}{ Overprotective } & Yes & 121 & 22.20 & 19 & 28.36 & \multirow[t]{2}{*}{1.28} & \multirow[t]{2}{*}{$*$} \\
\hline & No & 424 & 77.80 & 48 & 71.64 & & \\
\hline \multirow[t]{2}{*}{ Depriving/Neglectful } & Yes & 119 & 21.83 & 15 & 22.39 & \multirow[t]{2}{*}{0.01} & \multirow[t]{2}{*}{$*$} \\
\hline & No & 426 & 78.17 & 52 & 77.61 & & \\
\hline \multirow[t]{2}{*}{ Humiliating } & Yes & 113 & 20.73 & 15 & 22.39 & \multirow[t]{2}{*}{0.10} & \multirow[t]{2}{*}{$*$} \\
\hline & No & 432 & 79.27 & 52 & 77.61 & & \\
\hline \multirow[t]{2}{*}{ Guilt generating } & Yes & 145 & 26.61 & 25 & 37.31 & \multirow[t]{2}{*}{3.41} & \multirow[t]{2}{*}{ ** } \\
\hline & No & 400 & 73.39 & 42 & 62.69 & & \\
\hline \multirow[t]{2}{*}{ Stimulative } & Yes & 103 & 18.90 & 11 & 16.42 & \multirow[t]{2}{*}{0.24} & \multirow[t]{2}{*}{$*$} \\
\hline & No & 442 & 81.10 & 56 & 83.58 & & \\
\hline Affectionate & Yes & 54 & 9.91 & 6 & 8.96 & 0.06 & * \\
\hline
\end{tabular}

\begin{tabular}{|l|l|l|l|l|l|l|l|}
\hline & No & 491 & 90.09 & 61 & 91.04 & & \\
\hline Tolerant & Yes & 65 & 11.93 & 7 & 10.45 & 0.13 & $*$ \\
& No & 480 & 88.07 & 60 & 89.55 & & \\
\cline { 2 - 7 } & & & & & & & \\
\hline
\end{tabular}

Note: * Statistical significance of the results between groups is less than $95.0 \%$ ( $p>0.05$ ); ** Statistical significance of the results between groups is $95.0 \%(\mathrm{p}<0.05)$.

Our cases show that most parents instilled a feeling of guilt in their offsprings - 145 cases in group I (26.61\%), and 25 cases(37.31\%) in group II - statistically significant data $(\mathrm{p}$ $<0.05)$. Overprotective parenting was recorded in 121 cases $(22.20 \%)$ in group I and 19 cases $(28.36 \%)$ in group II; neglectful parenting: - 119 cases $(21.83 \%)$ and 15 cases $(22.39 \%)$ in group I and II, respectively, and humiliation parenting - 113 cases $(20.73 \%)$ in group I and 15 cases (22.39\%) in group II.

In the genesis of unfavorable dynamics of patient symptomatology in adult life, a major importance is given to long-term and often repeated psychological trauma, through the mechanism of "intricacy and summation", which represent risk factors for vulnerability to depression in adulthood $(14,15)$. According to literature data, significant vulnerability factors are considered early parental loss, through either death or separation, and marital status change (16). The loss of any parent in the first five years of life, as well as the loss of father during preadolescence are vulnerability factors for depressive episodes (14). Some studies show that $51 \%$ of orphan children developed depressive episodes in their adult life. (17) Emotional and physical abuse are factors that lower self-esteem, and trigger self-defeating defense mechanisms, thus generating the neurotic premorbid personality, which is a predictive factor for TRD.

The results of researches led to a wide interest related to the early experience of threat or "maternal deprivation", situations that later 
(1)

lead to a depressive state (19). The effect of separation depends on several factors, including the age of the child at the time of separation, the reasons for the separation, and child's previous relationships with his/her parents. Patients with reduced emotional attachments present major difficulties in establishing social relationships. Parental separation influences child's construction of their world and the formation of their personality by the identification and imitation of a model. Because, before being himself, the child is "another" or "others." This process was related to the pressure or repressions exerted by the parents on their child, thus the child becoming the "object" of the wishes, tendencies, emotions and aspirations of those around him (19). The consequences of father death or absence are often translated into the lack of social, material and emotional support from the mother. This is due to the fact that the mother is absent from home quite a long time in order to earn money, or she is very busy with household chores, she is dissatisfied and even depressed, and, thus, less able to pay attention to her children. These children also lacked love, empathy, and affection from their close relatives. Although the parents play the in roles in education, other close relatives, like grandparents, older brothers, etc. also contribute to child's formation.

Another loss-related predictor for the development of depression is the death of a parent when the child is around 9 years old. This is due to the fact that around this age the child becomes fully aware of the irreversibility character of death. (20)

Among other predisposing factors are various childhood psychological trauma such as physical abuse, which could render the hypothalamus-pituitary-adrenal system vulnerable for the rest of life, thus contributing to the emergence of depression when new stressful life events occur in adulthood. (20) The characteristics of psychological traumatic events in childhood are presented in Table 3.

Table 3. The characteristics of psychological traumatic events in childhood

\begin{tabular}{|c|c|c|c|c|c|c|c|}
\hline \multicolumn{2}{|l|}{ Situations } & \multicolumn{2}{|c|}{ Group I } & \multicolumn{2}{|c|}{ Group II } & \multirow[t]{2}{*}{$\chi^{2}$} & \multirow[t]{2}{*}{$\mathbf{p}$} \\
\hline & & Abs & $\%$ & Abs & $\%$ & & \\
\hline \multirow{2}{*}{$\begin{array}{l}\text { Loss of one } \\
\text { parent }\end{array}$} & Yes & 58 & 10.64 & 16 & 23.88 & \multirow[t]{2}{*}{9.84} & \multirow[t]{2}{*}{$* * *$} \\
\hline & No & 487 & 89.36 & 51 & 76.12 & & \\
\hline \multirow{2}{*}{$\begin{array}{l}\text { Loss of both } \\
\text { parents }\end{array}$} & Yes & 25 & 4.59 & 3 & 4.48 & \multirow[t]{2}{*}{0.00} & \multirow[t]{2}{*}{$*$} \\
\hline & No & 520 & 95.41 & 64 & 95.52 & & \\
\hline \multirow{2}{*}{$\begin{array}{l}\text { Economic or } \\
\text { moral decay } \\
\text { of the family }\end{array}$} & Yes & 102 & 18.72 & 13 & 19.40 & \multirow[t]{2}{*}{0.19} & \multirow[t]{2}{*}{$*$} \\
\hline & No & 443 & 81.28 & 54 & 80.60 & & \\
\hline \multirow{2}{*}{$\begin{array}{l}\text { Abandonment, } \\
\text { separation }\end{array}$} & Yes & 131 & 24.04 & 16 & 23.88 & \multirow[t]{2}{*}{0.00} & \multirow[t]{2}{*}{$*$} \\
\hline & No & 414 & 75.96 & 51 & 76.12 & & \\
\hline \multirow{2}{*}{$\begin{array}{l}\text { Deceptions, } \\
\text { lack of } \\
\text { emotional } \\
\text { support }\end{array}$} & Yes & 139 & 25.50 & 24 & 35.82 & \multirow[t]{2}{*}{3.25} & \multirow[t]{2}{*}{ *** } \\
\hline & No & 406 & 74.50 & 43 & 64.18 & & \\
\hline \multirow{2}{*}{$\begin{array}{l}\text { Physical } \\
\text { aggression }\end{array}$} & Yes & 43 & 7.89 & 1 & 1.49 & \multirow[t]{2}{*}{3.66} & \multirow[t]{2}{*}{$* *$} \\
\hline & No & 502 & 92.11 & 66 & 98.51 & & \\
\hline
\end{tabular}

Note: ABS=absolute; $\%=$ percent;

* Statistical significance of the results between the groups is less than $95.0 \%$ ( $p>$ $0.05)$.

**Statistical significance of the results between the groups is $95.0 \%$ ( $p<0.05$ ).

*** Statistical significance of the results between the groups is $99.0 \%$ ( $p<0.01$ ).

According to the data, the largest number of subjects experienced disappointments, low emotional support, group I - 139 cases (25.50\%), group II - 24 cases (35.82\%), statistically significant ( $\mathrm{p}<0,05$ ), but also abandonment and/or separation during childhood, group I - 131 cases (24.04\%), group II - 16 subjects (23.88\%), ( $>$ > 0.05). The results are statistically significant also in the case of the loss of a parent: group I - 58 cases $(10.64 \%)$, group II -16 cases $(23.88 \%)$, ( $\mathrm{p}<0.01)$, and physical abuse - group I - 43 cases $(7.89 \%)$, group II -1 cases $(1.49 \%)$, (p $<0.05)$.

No personality structure confers invulnerability to depression. According to 
\% researchers, depression usually occurs in the presence of specific personality traits that confer vulnerability, such as instability, anxiety, vulnerability to stress, obsessive behavior. Thus, dependent personality traits render people more vulnerable to events in the relationship domain, and the relatively more autonomous ones, are more sensitive to events related to their personal achievement (21).

Our data indicate that premorbid characteristics influence the development of depressive episodes with unfavorable dynamics, predictive factors for TRD (18). These people were predominantly polymorphic, often from an unstable, uncertain family environment, and lacking emotional warmth, tolerance, help and constructive discipline. The specific form of education induced the feeling of guilt, responsibility and increased emotional vulnerability. From our data, harmonious personality traits were underrepresented, group I - 44 cases $(8.07 \%$ ), group II - 3 cases, $(4.48 \%)$. The harmonious subjects were different as they were calm, communicative, active, and enjoyed life, had a uniform and quiet background of the affective mood, a wide range of interests and the ability to adapt quickly to new situations. In the family and at the workplace, they were appreciated as quiet, polite, kind, disciplined people, with welldefined goals in life and good family members (Table 4).

Table 4. Patient characteristics according to premorbid personality traits

\begin{tabular}{|c|c|c|c|c|c|c|c|}
\hline \multicolumn{2}{|l|}{ Traits } & \multicolumn{2}{|c|}{ Group I } & \multicolumn{2}{|c|}{ Group II } & \multirow[t]{2}{*}{$\chi^{2}$} & \multirow[t]{2}{*}{$\mathbf{P}$} \\
\hline & & Abs & $\%$ & Abs & $\%$ & & \\
\hline \multirow[t]{2}{*}{ Harmonious } & Yes & 44 & 8.07 & 3 & 4.48 & \multirow[t]{2}{*}{1.09} & \multirow[t]{2}{*}{$*$} \\
\hline & No & 501 & 91.93 & 64 & 95.52 & & \\
\hline \multirow[t]{2}{*}{ Rigid } & Yes & 65 & 11.93 & 10 & 14.93 & \multirow[t]{2}{*}{0.50} & \multirow[t]{2}{*}{$*$} \\
\hline & No & 480 & 88.07 & 57 & 85.07 & & \\
\hline \multirow[t]{2}{*}{ Scrupulous } & Yes & 120 & 22.02 & 21 & 31.34 & \multirow[t]{2}{*}{2.93} & \multirow[t]{2}{*}{$*$} \\
\hline & No & 425 & 77.98 & 46 & 68.66 & & \\
\hline \multirow[t]{2}{*}{ Anxious } & Yes & 130 & 23.85 & 24 & 35.82 & \multirow[t]{2}{*}{4.54} & \multirow[t]{2}{*}{ ** } \\
\hline & No & 415 & 76.15 & 43 & 64.18 & & \\
\hline
\end{tabular}

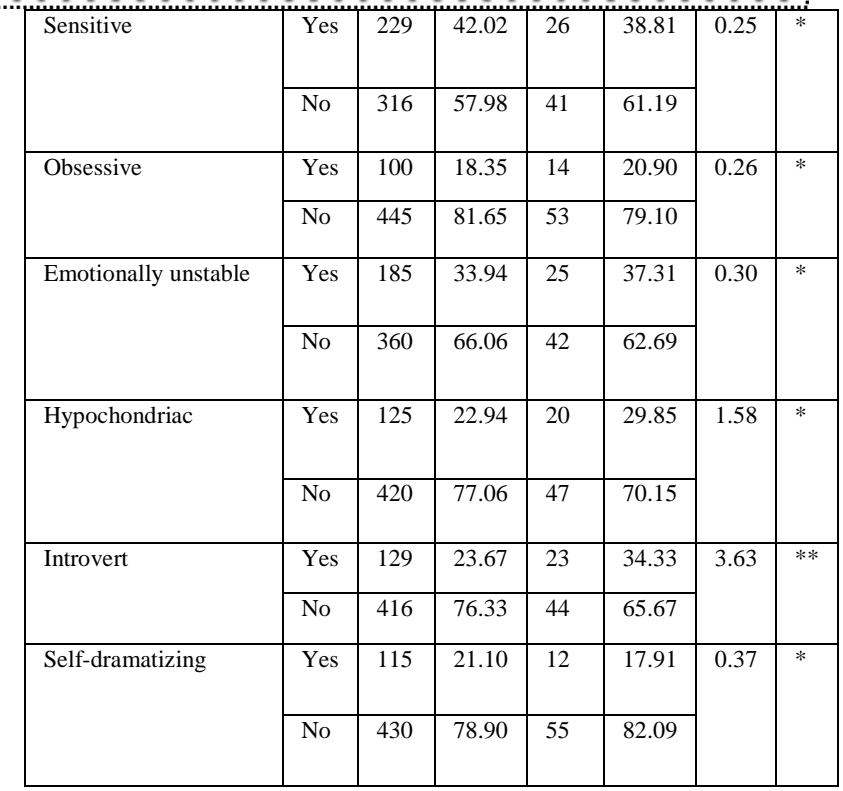

Note: * Statistical significance of the results between groups is less than $95.0 \%$ ( $p>0.05$ ); ** Statistical significance of the results between groups is less than $95.0 \%$ ( $p<0.05$ ).

According to the data on the personality structure of our study patients different traits were present, with sensitivity ranking first: group I - $229(42.02 \%)$ cases, group II - 26 $(38.81 \%)$ cases, followed by emotional lability: group I - 185 (33.94\%) of cases, group II $-25(37.31 \%)$ of cases. Statistically significant results $(\mathrm{p}<0.05)$ we recorded for anxiety in the premorbid period: group I $130(23.85 \%)$ cases, group II - 24 (35.82\%) cases, and introversion: group I - 129 (23.67\%) cases, group II - 23 (34.33\%) cases. Environmental precipitating factors are risk conditions in the development of TRD, and the presence of vulnerability factors in the relationship domain facilitates the development of the depressive effects of these factors $(22,23)$. The data recorded in 272 $(44.44 \%)$ patients indicate that they had little economic resources, were of low economic status and experienced material shortage.

Stressful life events (lack of job, lack of social support, tense family microclimate, divorce lawsuit, prolonged separation following emigration, grief after losing a family member, impact of physical and sexual abuse) 
(1)

influence the development and course of different clinical forms of RTD $(24,25)$.

The distribution of the psychotraumatic events just before the onset of the depressive episode in the present study are shown in fig. 1.

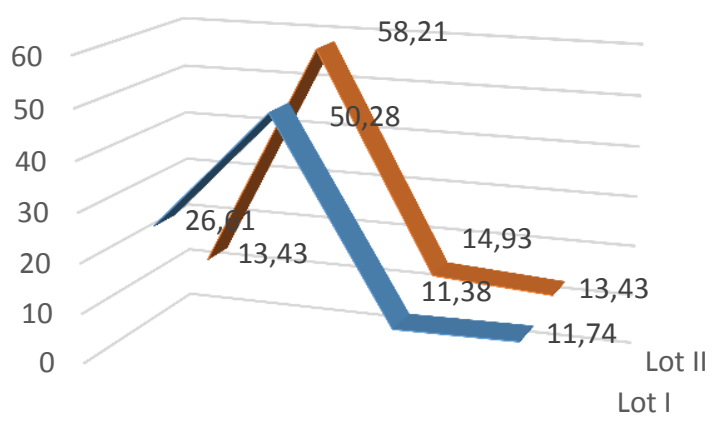

- Lot I Lot II

Fig. 1. Group distribution of psychotraumatic events before the onset of the depressive episode (\%).

From the analysis of the obtained results we found that the majority of patients, both in group I - $274(50.28 \%)$ and in group II - 39 (58.21\%) declared they had experienced negative events, which affected their personal life (death of a family member, divorce, intimate issues). Professional reasons (unemployment, retirement, job change) were invoked by $62(11.38 \%)$ of group I patients and of 10 (14.93\%) in group II.

Researchers opine that family microclimate exerts a significant influence on the onset of depressive disorders, establishing that the risk of developing a refractory depressive state is higher in single, solitary, divorced persons, and in people without children, etc. (26). One of the precipitating factors most frequently invoked in the onset of affective disorder is separation from/loss of someone close, which is validated by successive studies (27). Stressful life events, especially those related to the loss of a significant other, can play a determining role in vulnerability to depression, whether the loss is real (for example, death, and divorce) or symbolic (such as, loss of trust with trusted person or life partner). Even if until becoming ill people lived a harmonious marital life, the illness itself can lead to serious problems. That is the reason why harmonizing family relationships is important. These relationships need correction because family provides foundation for building self-confidence.

The study patients showed that they were vulnerable to stressful events in their relationships and especially to their accumulation. Moreover, people with less interpersonal resources, insufficient family support may also be less responsive to antidepressant treatment (28).

Similarly, other conditions such as lack of emotion sharing, low emotional support, lack of intimate relationships, hostile attitude towards children, caring for children up to 14 years, unsatisfactory housing, jealousy, sexually transmitted diseases, lack of trust, physical aggression, feeling of loneliness, failure in personal life, emigration of the partner, abandonment, separation, divorce, cause instability of personal life, with a direct impact on family (27). In these situations, the subjects transfer the responsibility of developing the morbid events to their spouse. Attenuation of psychotraumatic situations has little influence on the improvement of patient condition, and the condition often gets worse under the action of "neutral" factors, which do not have pathogenic significance (insignificant insulting remarks, daily worries, minor conflicts, etc.). The results obtained by us are presented in Table 5.

Table 5. Characteristics of the situations created in one's own family

\begin{tabular}{|l|l|l|l|l|l|l|l|}
\hline \multicolumn{2}{|c|}{ Situations } & \multicolumn{2}{|l|}{ Group I } & \multicolumn{2}{|l|}{ Group II } & \multirow{2}{*}{$\mathbf{2}$} & \multirow{2}{*}{ P } \\
\cline { 2 - 6 } \multicolumn{2}{|c|}{} & abs & $\%$ & abs & $\%$ & & \\
\hline $\begin{array}{l}\text { No emotion } \\
\text { sharing }\end{array}$ & Yes & 96 & 17.61 & 15 & 22.39 & 0.92 & $*$ \\
& No & 449 & 82.39 & 52 & 77.61 & & \\
\cline { 2 - 6 } & & & & & & & \\
\hline
\end{tabular}




\begin{tabular}{|c|c|c|c|c|c|c|c|}
\hline \multirow{2}{*}{$\begin{array}{l}\text { Lack of } \\
\text { emotional } \\
\text { support }\end{array}$} & Yes & 149 & 27.34 & 20 & 29.85 & \multirow[t]{2}{*}{0.19} & \multirow[t]{2}{*}{$*$} \\
\hline & No & 396 & 72.66 & 47 & 70.15 & & \\
\hline \multirow{2}{*}{$\begin{array}{l}\text { Absence of } \\
\text { intimate relations }\end{array}$} & Yes & 123 & 22.57 & 18 & 26.87 & \multirow[t]{2}{*}{0.62} & \multirow[t]{2}{*}{$*$} \\
\hline & No & 422 & 77.43 & 49 & 73.13 & & \\
\hline \multirow{2}{*}{$\begin{array}{l}\text { Hostile attitude } \\
\text { towards children }\end{array}$} & Yes & 67 & 12.29 & 11 & 16.42 & \multirow[t]{2}{*}{0.91} & \multirow[t]{2}{*}{$*$} \\
\hline & No & 478 & 87.71 & 56 & 83.58 & & \\
\hline \multirow{2}{*}{$\begin{array}{lr}\text { Caring for } \\
\text { children until } 14 \\
\text { years old }\end{array}$} & Yes & 72 & 13.21 & 9 & 13.43 & \multirow[t]{2}{*}{0.00} & \multirow[t]{2}{*}{$*$} \\
\hline & No & 473 & 86.79 & 58 & 86.57 & & \\
\hline \multirow{2}{*}{$\begin{array}{l}\text { Unsatisfactory } \\
\text { living condition }\end{array}$} & Yes & 53 & 9.72 & 5 & 7.46 & \multirow[t]{2}{*}{0.36} & \multirow[t]{2}{*}{$*$} \\
\hline & No & 492 & 90.28 & 62 & 92.54 & & \\
\hline \multirow[t]{2}{*}{ Lack of trust } & Yes & 123 & 22.57 & 19 & 28.36 & \multirow[t]{2}{*}{1.12} & \multirow[t]{2}{*}{$*$} \\
\hline & No & 422 & 77.43 & 48 & 71.64 & & \\
\hline \multirow{2}{*}{$\begin{array}{l}\text { Physical } \\
\text { aggression }\end{array}$} & Yes & 65 & 11.93 & 6 & 8.96 & \multirow[t]{2}{*}{0.51} & \multirow[t]{2}{*}{$*$} \\
\hline & No & 480 & 88.07 & 61 & 91.04 & & \\
\hline \multirow{2}{*}{$\begin{array}{l}\text { Loneliness, } \\
\text { failure } \\
\text { personal life }\end{array}$} & Yes & 126 & 23.12 & 17 & 25.37 & \multirow[t]{2}{*}{0.17} & \multirow[t]{2}{*}{$*$} \\
\hline & No & 419 & 76.88 & 50 & 74.63 & & \\
\hline \multirow{2}{*}{$\begin{array}{l}\text { Spouse } \\
\text { emigration }\end{array}$} & Yes & 99 & 18.17 & 12 & 17.91 & \multirow[t]{2}{*}{0.00} & \multirow[t]{2}{*}{$*$} \\
\hline & No & 446 & 81.83 & 55 & 82.09 & & \\
\hline \multirow{2}{*}{$\begin{array}{l}\text { Abandonment, } \\
\text { separation, } \\
\text { divorce, death }\end{array}$} & Yes & 219 & 40.18 & 28 & 41,79 & \multirow[t]{2}{*}{0.06} & * \\
\hline & No & 326 & 59.82 & 39 & 58,21 & & \\
\hline
\end{tabular}

Note: *Statistical significance of the results between groups is less than $95.0 \%$ ( $p>0.05$ )

The presented data show that the majority of patients experienced abandonment, separation, divorce, death in their own family: group I - 219 (40.18\%) cases, group II -28 (41.79\%) of cases; low level of emotional support: group I - 149 (27.34\%) of cases, group II - $20(29.85 \%)$ of cases; feeling of loneliness, failure in personal life: group I $126(23.12 \%)$ cases, group II $-17(25.37 \%)$ cases.

There was a predominance of subjects with low social support (as they were left alone following divorce, migration, convictions, integration, acceptance, and discrimination issues), low socioeconomic status, unfavorable living conditions, unemployment, and ill parents.

The harmful somatogenic and organic brain factors may have a particular influence on the course of depressive disorders as by affecting the body they open the way for the occurrence of psychopathological symptoms. Somatic influences, surgery, and alcohol abuse potentiate a prolonged disease course, playing a significant role in the development of an unfavorable dynamic. If these conditions improve, the various psychopathological manifestations would decrease in intensity.

Of the somatic diseases presented by our patients, chronic gastrointestinal diseases and diseases of the respiratory, cardiovascular and urogenital systems were the most common. In the majority of patients these disorders had been associated with the presence of other factors, taking an active part in symptomformation. In case of somatogenic disorders, the depressive disorder manifests with a hyperbolization of the existing pathological sensations, and depressive symptoms are complicated by asthenic, obsessive-phobic and hypochondriac symptoms. The course was influenced by the presence of craniocerebral trauma, neuroinfections, and different instability of neurotic level, disorders that when not treated cause a prolonged course of the depressive disorder.

The distribution of patients according to the associated disorders in the premorbid period is presented in Table 6 .

Table 6. Distribution of disorders in the premorbid period

\begin{tabular}{|c|c|c|c|c|c|c|c|}
\hline \multicolumn{2}{|l|}{ Nosological entity } & \multicolumn{2}{|c|}{ Group I } & \multicolumn{2}{|c|}{ Group II } & \multirow[t]{2}{*}{$\chi^{2}$} & \multirow[t]{2}{*}{$\mathbf{p}$} \\
\hline & & Abs & $\%$ & Abs & $\%$ & & \\
\hline \multirow[t]{2}{*}{ Somatic disorders } & Yes & 294 & 53.94 & 33 & & \multirow[t]{2}{*}{0.53} & \multirow[t]{2}{*}{$*$} \\
\hline & No & 251 & 46.06 & 34 & & & \\
\hline \multirow[t]{2}{*}{ Surgical interventions } & Yes & 94 & 17.25 & 12 & & \multirow[t]{2}{*}{0.02} & \multirow[t]{2}{*}{$*$} \\
\hline & No & 451 & 82.75 & 55 & & & \\
\hline \multirow[t]{2}{*}{ Craniocerebral trauma } & Yes & 137 & 25.14 & 22 & & \multirow[t]{2}{*}{1.84} & \multirow[t]{2}{*}{$*$} \\
\hline & No & 408 & 74.86 & 45 & & & \\
\hline \multirow{2}{*}{$\begin{array}{l}\text { Psychoactive substance } \\
\text { use }\end{array}$} & Yes & 69 & 12.66 & 15 & & \multirow[t]{2}{*}{4.77} & \multirow[t]{2}{*}{ *** } \\
\hline & No & 476 & 87.34 & 52 & & & \\
\hline \multirow{2}{*}{$\begin{array}{l}\text { Affective } \\
\text { oscillations/instability }\end{array}$} & Yes & 204 & 37.43 & 25 & & \multirow[t]{2}{*}{0.00} & \multirow[t]{2}{*}{$*$} \\
\hline & No & 341 & 62.57 & 42 & & & \\
\hline
\end{tabular}

Note: * Statistical significance of the results between groups is less than $95.0 \%$ ( $p>0.05$ ); ** Statistical significance of the results between groups is $95.0 \%(\mathrm{p}<0.05)$. 


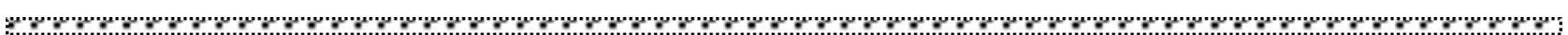

Studying the distribution of harmful factors in the premorbid period revealed that the number of subjects with somatic disorders and affective instability was much higher than that of those with other factors - 294 (53.94\%) cases in group I and $33(49,25 \%)$ in group II, and $204(37.43 \%)$ cases in group I and 25 cases, $(37.31 \%)$ in group II ( $>>0.05)$, respectively. However, statistically significant $(\mathrm{p}<0.05)$ is the comparison of study groups in terms of psychoactive substances use: group I-69 (12.66\%), group II-15 (22.39\%) cases.

\section{DISCUSSION}

During the premorbid period, the study patients presented numerous predisposing and precipitating factors with a role in the development of therapeutic resistance. The most frequent ones were: hereditary factors, pathological personalities, personality disorders, different stressful conditions in the family environment, past and current medical conditions.

It is worth mentioning that stressful family situations were often linked to unstable personal life (absence of the spouse, personality differences between spouses, sexual disharmony), professional activityrelated issues (conflicts, dismissal from work, professional dissatisfaction), but also insurmountable financial and housing problems (lack of living space, insufficient earnings). In order for such conditions to become pathogenic, childhood educational experiences and current traumatic events have to merge to a variable degree.

\section{CONCLUSIONS}

1. Affective disorders were the most common family history finding: $25.69 \%$ cases in group I, $26.87 \%$ in group II, followed by somatic disorders: $15.96 \%$ in group I and $14.93 \%$ in group II and stress-related disorders : $11.01 \%$, in group I and 16.42\% in group II. Regarding the attitude of parents towards their children, it was found that most parents instilled the feeling of guilt in their offsprings - $26.61 \%$ cases in group I and $37.31 \%$ in group II, followed by overprotective parenting $22.20 \%$ (group I) and $28.36 \%$ (group II), depriving or neglectful parenting: first batch - $21.83 \%$ (group I) and $22.39 \%$ (group II) and humiliation parenting: $20.73 \%$ (group I) and $22.39 \%$ (group II). 2. The lack of an organized, stable and safe family had a profound adverse effect on mental development during childhood. Data analysis shows that the largest number of subjects experienced disappointments, low level of emotional support during childhood, group I $-25.50 \%$, group II $35.82 \%$, ( $\mathrm{p}<0.05$ ), abandonment, parental separation during childhood, group I $-24.04 \%$, group II $-23.88 \%$, (p>0.05), and also the loss of one parents: group I $-10.64 \%$, group II $-23.88 \%$, ( $<<$ 0.01 ), the use of physical force towards children - group I - 7.89\%, group II - 1.49\%, ( $<<0.05)$.

3. In the personality structure of the patients different traits were present, with sensitivity being the most common: group I $-42.02 \%$ cases, group II $-38.81 \%$ cases ( $p>0.05$ ), followed by emotional lability: group I - 33.94\%, group II- $37.31 \%$ ( $>>0.05$ ); anxiety in the premorbid period: group I - 23.85\%, group II - 35.82\% (p <0.05); introversion: group I-23.67\%, group II-34.33\% (p $<0.05)$.

4. Most patients, both in group I - 50.28\% cases and in group II - 58.21\% declared experiencing negative events in the last months, which affected their personal life. Professional reasons were invoked by $11.38 \%$ of group I patients and $14.93 \%$ of group II patients. The obtained data show that most patients experienced abandonment, parental separation, divorce, death in their own families: group I - 40.18\% cases, group II - $41.79 \%$ cases, low level of emotional support: group I - $27.34 \%$, group II $-29.85 \%$, and feelings of loneliness, failure in personal life: group I - $23.12 \%$, group II $1725.37 \%$ cases. 
5. Studying the distribution of harmful factors in the premorbid period, it was found that the number of subjects presenting somatic disorders was much higher than of those with other factors: $53.94 \%$ cases in group I and $49.25 \%$ in group II followed by affective instability of the neurotic level - group I $37.43 \%$ of the cases and $37.31 \%$ in group II ( $>>0.05$ ). But statistically significant ( $p$ $<0.05$ ) is the comparison between the two groups in terms of psychoactive substances use: group I $12.66 \%$ and group II $-22.39 \%$.

\section{ACKNOWLEDGEMENTS AND DISCLOSURES}

The authors declare that they have no potential conflicts of interest to disclose.

\section{REFERENCES}

1. Center for Behavioral Health Statistics and Quality. Results from the 2015 National Survey on Drug Use and Health: Detailed Tables. Rockville, MD: Substance Abuse and Mental Health Services Administration; 2016.

2. Wang PS, Lane M, Olfson M, et al. Twelve-month use of mental health services in the United States: results from the National Comorbidity Survey Replication. Arch Gen Psychiatry. 2005 Jun;62(6):629-40.

3. Trivedi MH, Rush AJ, Wisniewski SR, et al. Evaluation of outcomes with citalopram for depression using measurement-based care in STAR*D: implications for clinical practice. Am J Psychiatry. 2006 Jan;163(1):28-40.

4. Berlim MT, Fleck MP, Turecki G. Current trends in the assessment and somatic treatment of resistant/refractory major depression: an overview. Ann Med. 2008;40(2):149-59.

5. Kessler RC, Chiu WT, Demler O, et al. Prevalence, severity, and comorbidity of 12-month DSMIV disorders in the National Comorbidity Survey Replication. Arch Gen Psychiatry. 2005 Jun;62(6):617-27.

6. Greden JF. The burden of disease for treatment-resistant depression. J Clin Psychiatry. 2001;62 Suppl 16:26-31

7. Gibson TB, Jing Y, Smith Carls G, et al. Cost burden of treatment resistance in patients with depression. Am J Manag Care. 2010 May;16(5):370-7.

8. Crown WH, Finkelstein S, Berndt ER, et al. The impact of treatment-resistant depression on health care utilization and costs. J Clin Psychiatry. 2002 Nov;63(11):963-71.

9. Friedman ES, Anderson IM. Handbook of Depression. London. Springer Healthcare, 2014, 105 p.

10. Hölzel L, Härter M, Reese C, Kriston L. Risk factors for chronic depression-a systematic review. J Affect Disord. 2011; 129:1-13.

11. Husain MM, Rush AJ, Wisniewski SR, McClintock SM, Fava M, Nierenberg AA, Davis L, Balasubramani GK, Young E, Albala AA, Trivedi MH. Family history of depression and therapeutic outcome: findings from STAR*D. J Clin Psychiatry. 2009 Feb; 70(2):185-95.

12. Kennedy SH, Giacobbe P. Treatment resistant depression - advances in somatic therapies. Ann Clin Psychiatry. 2007;19:279-287.

13. Corya SA, Williamson D, Sanger TM, Briggs SD, Case M, Tollefson G. A randomized, double-blind comparison of olanzapine/fluoxetine combination, olanzapine, fluoxetine, and venlafaxine in treatment-resistant depression. Depress Anxiety. 2006; 23(6):364-72.

14. Bowlby, J. Attachment and loss, Vol. 2. „Separation, anxiety and anger”. Hogarth Press, London. 1973.

15. Greden JF. The burden of disease for treatment-resistant depression. J Clin Psychiatry. 2001; 62 Suppl 16:26-31.

16. Breier A., Kelsoe J.R., Kirwin P.D. and al. Early parental loss and development of adult psychopathology. Arch.Gen. Psychiatr. 1988; 45, 987-993.

17. Brown F. Depression and childhood bereavement. Journal of Mental Science. 1961; 107: 754-777.

18. Scott J., Eccleston D. Prediction, treatment and prognosis of major depressive disorder. International Clinical Psychopharmacology. 1991; 6 (suppl.1): 41-49.

19. Bowlby, J. Attachment and loss, Vol. 3. „Loss, sadness and depression”. Basic Books. New York. 1980.

20. Maalouf FT, Atwi M, Brent DA. Treatment-resistant depression in adolescents: review and updates on clinical management. Depress Anxiety. 2011;28:946-954.

21. Frank E., Kupfer D.J., Perel J.M. and al. Three-year outcomes for maintenance therapies in recurrent depression. Arch Gen Psychiatry. 1990; 47:1093-9.

22. Rodjers B. Models of stress, vulnerability and affective disorder. J. Affect. Disord. 1991; 31:1-13. 

23. Rush AJ, Warden D, Wisniewski SR, et al. STAR*D: revising conventional wisdom. CNS Drugs.2009; 23:627647.

24. Pizzagalli DA. Depression, stress, and anhedonia: toward a synthesis and integrated model. Annu Rev Clin Psychol. 2014; 10:393-423.

25. Shamseddeen W, Asarnow JR, Clarke G, et al. Impact of physical and sexual abuse on treatment response in the Treatment of Resistant Depression in Adolescent Study (TORDIA) J Am Acad Child Adolesc Psychiatry. 2011; 50:293-301.

26. Matsunaga $\mathrm{M}$ and al. Psychosocial functioning in patients with Treatment-Resistant Depression after group cognitive behavioral therapy. BMC Psychiatry. 2010 Mar 16;10:22.

27. Goodwin F.K., Jamison K.R. Manic depressive illness. New York, Oxford University Press, 1990.

28. Thase ME, Rush JA. Treatment-resistant depression. In: Bloom FE, Kupfer DJ, editors. Psychopharmacology. New York, NY: Raven; 1995.

\section{Correspondence:}

Ghenadie Cărăuşu, „Nicolae Testemiţanu” State University of Medicine and Pharmacy, Bd. Ştefan cel Mare şi Sfânt, no. 165, code 2004, Chişinău, Republic of Moldova Tel.: +373 69373670, drcarausu@ yahoo.com

Submission:10 jun 2019

Acceptance: 30 aug 2019 